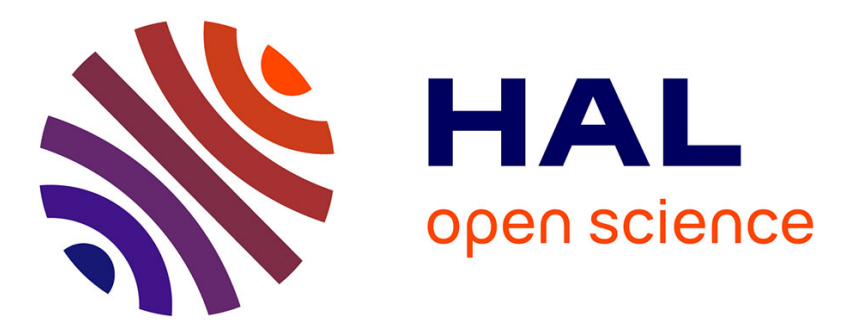

\title{
ScvO 2 changes after red-blood-cell transfusion for anaemia in cardiothoracic and vascular ICU patients: an observational study
}

M Zeroual, Gianluca Samarani, J. Gallais, G. Culas, M. Saour, M. Mourad, Philippe Gaudard, Pascal Colson

\section{To cite this version:}

M Zeroual, Gianluca Samarani, J. Gallais, G. Culas, M. Saour, et al.. ScvO 2 changes after red-bloodcell transfusion for anaemia in cardiothoracic and vascular ICU patients: an observational study. Vox Sanguinis, 2018, 113 (2), pp.136-142. 10.1111/vox.12610 . hal-01788836

\section{HAL Id: hal-01788836 \\ https://hal.umontpellier.fr/hal-01788836}

Submitted on 24 Jan 2020

HAL is a multi-disciplinary open access archive for the deposit and dissemination of scientific research documents, whether they are published or not. The documents may come from teaching and research institutions in France or abroad, or from public or private research centers.
L'archive ouverte pluridisciplinaire HAL, est destinée au dépôt et à la diffusion de documents scientifiques de niveau recherche, publiés ou non, émanant des établissements d'enseignement et de recherche français ou étrangers, des laboratoires publics ou privés. 


\title{
$\mathrm{ScvO}_{2}$ changes after red-blood-cell transfusion for anaemia in cardiothoracic and vascular ICU patients: an observational study
}

\author{
N. Zeroual, ${ }^{1}$ G. Samarani, ${ }^{1}$ J. Gallais, ${ }^{1}$ G. Culas, ${ }^{1}$ M. Saour, ${ }^{1}$ M. Mourad, ${ }^{1}$ P. Gaudard ${ }^{1,2}$ \& P. H. Colson ${ }^{1,3}$, \\ ${ }^{1}$ Département d'anesthésie réanimation Arnaud de Villeneuve, Centre Hospitalier Régional et Universitaire, Montpellier, France \\ ${ }^{2}$ PhyMedExp, INSERM U1046, University of Montpellier, Montpellier, France \\ ${ }^{3}$ Institut de Génomique Fonctionnelle Endocrinology Department, CNRS UMR 5203, INSERM U1191, University of Montpellier, Montpellier, France
}

Background and Objectives Haemoglobin threshold for transfusion has been significantly decreased, but haemoglobin plasma concentration may not be sufficient to assess the need of red-blood-cell (RBC) transfusion. Central venous oxygen saturation $\left(\mathrm{ScvO}_{2}\right)$ is a clue of metabolic matching between $\mathrm{O}_{2}$ transport and consumption, which could help to assess when transfusion is appropriate once anaemia has been diagnosed in ICU patients.

Materials and Methods Adult patients admitted consecutively to a cardiothoracic and vascular ICU were included in a prospective, observational and single-centre study over a 6-month period (September 2014 to February 2015), provided they were transfused with RBC. Patients with active bleeding or in unstable condition were excluded. Haemoglobin and $\mathrm{ScvO}_{2}$ were collected through a central venous catheter before and after transfusion. In order to identify a $\mathrm{ScvO}_{2}$ threshold, analysis of $\mathrm{ScvO}_{2}$ changes after transfusion was performed.

Results Fifty-three patients received $100 \mathrm{RBC}$ transfusions. Haemoglobin at the time of transfusion was $7 \cdot 2 \mathrm{~g} / \mathrm{dl}$ [6.8-7.7], while $\mathrm{ScvO}_{2}$ was 66.9\% [60-73]. A 5\% increase in $\mathrm{ScvO}_{2}$ after transfusion has the best specificity and positive predictive values, with a $\mathrm{ScvO}_{2}$ threshold of 65\%. After transfusion (RBC units, 2 [1-2]), $\mathrm{ScvO}_{2}$ increased only in patients with $\mathrm{ScvO}_{2} \leq 65 \%$, from 58\% [53-62] to 69\% [64-73] $(P<0.001)$.

Conclusion In anaemic patients, RBC transfusion induced a significant increase in $\mathrm{ScvO}_{2}$, provided it was low before transfusion. A 65\% cut-off value of $\mathrm{ScvO}_{2}$ before transfusion showed good specificity and good positive predictive value for a 5\% increase after transfusion.

Key words: anaemia, ICU, $\mathrm{ScvO}_{2}$, transfusion.

\section{Introduction}

Anaemia occurs frequently during critical illness. A haemoglobin concentration $(\mathrm{Hb})$ less than $12 \mathrm{~g} / \mathrm{dl}$ is common in an ICU, even more likely after cardiac surgery [1-4].

Correspondence: Pascal H. Colson, Département d'anesthésie-réanimation "Arnaud de Villeneuve", Centre Hospitalier Universitaire de Montpellier, 371 avenue Doyen Giraud, 34295 Montpellier Cedex 5, France E-mail: p-colson@chu-montpellier.fr

Zeroual and Samarani contributed equally to the manuscript.
Optimal management of the anaemia of critical illness is controversial. Up to $50 \%$ of ICU patients receive redblood-cell (RBC) transfusions [5, 6], out of which only $20 \%$ are to treat haemorrhage [1]. In cardiac surgery, the majority of the patients receive 3 or less RBC units [4]. However, the benefit-risk balance of a blood transfusion is a serious concern since several studies have shown that it may be associated with increased morbidity and mortality, even for few RBC units [7-9].

The decision to transfuse is currently referred to guidelines based on the $\mathrm{Hb}$, and a threshold of $7-9 \mathrm{~g} / \mathrm{dl}$ is 
recommended [10, 11]. Nevertheless, several authors have criticized a highly restrictive transfusion strategy [12-14]. A recent study, which compared restrictive vs. liberal strategy in post-cardiac surgery patients $(\mathrm{Hb}<7.5 \mathrm{~g} / \mathrm{dl}$ and $<9 \mathrm{~g} / \mathrm{dl}$, respectively), showed no difference between the two strategies in morbidity, although there was an increase in 3-month mortality in the restrictive group [15].

Therefore, $\mathrm{Hb}$ level may not be sufficient to assess the need for transfusion.

$\mathrm{As} \mathrm{Hb}$ is an oxygen carrier, the question is whether an increased $\mathrm{Hb}$ following transfusion matched the metabolic demand. A possible option is to measure mixed venous oxygen haemoglobin saturation $\left(\mathrm{SvO}_{2}\right)$, which reflects the balance between oxygen delivery and oxygen tissue consumption. To measure $\mathrm{SvO}_{2}$, a pulmonary artery catheter is required, but central venous oxygen haemoglobin saturation $\left(\mathrm{ScvO}_{2}\right)$ requires only a blood sample collected from central venous line. $\mathrm{ScvO}_{2}$ represents the oxygen $\mathrm{Hb}$ saturation of the superior vena cava territory, and therefore, it does not take into account the oxygen saturation of the inferior vena cava compartment and coronary sinus. Despite a lack of exact numerical equivalence, their variations are parallel with a satisfactory correlation $[16,17]$.

We proposed to study the effect of blood transfusion on $\mathrm{ScvO}_{2}$ in anaemic patients admitted to a cardiovascular and thoracic ICU.

\section{Material and methods}

This is a prospective, observational single-centre study conducted over a 6-month period from September 2014 to February 2015, in a 14-bed cardiovascular and thoracic ICU at the Montpellier Academic Hospital, France. The study was submitted to the Montpellier University Hospital institutional review board, which, because of the observational nature of the study, waived the need for informed consent.

\section{Patients}

All adult patients admitted consecutively to the ICU were included, provided they had an indication for RBC transfusion $(\mathrm{Hb}<9 \mathrm{~g} / \mathrm{dl}$, based on European Society of Anaesthesiologists Guidelines [18]), and a central venous catheter located in the superior vena cava territory (subclavian vein or internal jugular vein). Central venous catheter position was verified by chest X-ray in the immediate postoperative period.

In order to evaluate anaemia in the absence of critical conditions, patients with the following conditions were excluded: acute bleeding requiring transfusion of more than $4 \mathrm{RBC}$ units in $24 \mathrm{~h}$ or requiring a second operation for homeostasis (severe stage based on the criteria of the Universal Definition for Perioperative Bleeding [19]), patients who had major changes in respiratory therapy (change in mechanical ventilation mode or $\mathrm{FiO}_{2}$ concentration $>15 \%$ ), or in hemodynamic treatment (fluid volume loading, introduction of catecholamine or a dose increase of more than $20 \%$, or change in transient circulatory support settings), or change in sedation level between the two measurements of $\mathrm{ScvO}_{2}$.

\section{Transfusion}

RBC transfusion was managed as routinely, according to national guidelines (Agence Française de Sécurité Sanitaire des Produits de Santé, AFSSAPS 2002).

The number of RBC units (NRBC) to be transfused depended on patient's estimated blood volume (VST), Hb concentration before transfusion ( $\mathrm{Hbi}$ ) and expected $\mathrm{Hb}$ concentration after transfusion ( $\mathrm{Hbd}$, i.e. $9 \mathrm{~g} / \mathrm{dl}$ ), and the $\mathrm{Hb}$ concentration of the RBC unit (QHbRBC) according roughly to the following formula:

$\mathrm{N}_{\mathrm{RBC}}=(\mathrm{VST} / 100)\left(\mathrm{Hb}_{d}-\mathrm{Hb}_{i}\right) / \mathrm{QHb}_{\mathrm{RBC}}$

\section{Measurements}

Besides patient characteristics, hemodynamic parameters, sedation (Richmond Agitation-Sedation Scale, RASS) and pain (behaviour pain score, BPS) scores, respiratory parameters, cardiac support (inotropes and/or assistance) and $\mathrm{Hb}$ level were recorded at the time the decision to transfuse was made. The number of RBC units and therapeutic changes between the two samples of $\mathrm{ScvO}_{2}$ were also collected.

$\mathrm{ScvO}_{2}$ was measured by cooxymetry with a point-ofcare blood gas analyser located in the ICU (Instrumentation Laboratory, GEM 4000 Premier, USA) from blood samples taken in the superior vena cava through the central venous catheter, before and after RBC transfusion.

\section{Statistical analysis}

Quantitative variables are expressed as median and 25-75 interquartile [IQ], qualitative variables as a percentage. Statistical analysis was performed using the Mann-Whitney nonparametric model for quantitative variables and chi-squared test for qualitative variables.

The relationship between $\mathrm{Hb}$ and $\mathrm{ScvO}_{2}$ was analysed by Spearman rank correlation coefficient.

To determine the best $\mathrm{ScvO}_{2}$ value to predict an increase in $\mathrm{ScvO}_{2}$ following transfusion, an analysis of receiver operating characteristics (ROC) curves was performed using four levels of $\mathrm{ScvO}_{2}$ increase $(5,10,15$ and 
20\%). We anticipated choosing the $\mathrm{ScvO}_{2}$ with the best positive predictive value, able to select patients who may benefit of a $\mathrm{ScvO}_{2}$ increase after transfusion with the lowest rate of false positives.

The statistical analyses were performed with GRAPH PAD PRISM (version 5.0, 2008) and XLSTAT 7.5.2 (Addinsoft, Brooklyn, NY). Statistical significance was considered achieved with an alpha risk of $<5 \%(P<0.05)$.

\section{Results}

\section{Population studied}

Fifty-three ICU patients had received transfusions.

Patients' medical history and admission pattern are reported in Table 1. Most patients were admitted following surgery $(40,76 \%)$ and others for medical issues including temporary circulatory extracorporeal assistance (8, 15\%). Transfusion episode per patient was 1 [1, 2], and most patients $(78 \%)$ had one or two transfusion episodes, which resulted in a total of 104 RBC transfusions.

Table 1 Patient characteristics

\begin{tabular}{|c|c|}
\hline & $\begin{array}{l}\text { Patient population } \\
(n=53)\end{array}$ \\
\hline Age, years, median [IO] & $67[57-73]$ \\
\hline Male, $n(\%)$ & $36(68)$ \\
\hline \multicolumn{2}{|l|}{ Medical history } \\
\hline Diabetes, $n(\%)$ & $15(28)$ \\
\hline Hypertension, $n(\%)$ & $27(51)$ \\
\hline Coronary artery disease, $n(\%)$ & $27(51)$ \\
\hline Chronic renal failure, $n(\%)$ & $8(15)$ \\
\hline LVEF, \%, median [IO] & $20[15-40]$ \\
\hline SAPS II, median [IO] & $52[36-60]$ \\
\hline \multicolumn{2}{|l|}{ Admission pattern } \\
\hline Cardiac surgery, $n(\%)$ & $25(47)$ \\
\hline $\mathrm{CABG}, n(\%)$ & $4(7 \cdot 5)$ \\
\hline Valvular, $n(\%)$ & $8(17)$ \\
\hline CABG \& valvular, $n(\%)$ & $2(3 \cdot 7)$ \\
\hline Aortic dissection, $n(\%)$ & $2(3 \cdot 7)$ \\
\hline LVAD, $n(\%)$ & $7(13 \cdot 2)$ \\
\hline Other, $n(\%)$ & $2(3 \cdot 7)$ \\
\hline Major thoracic surgery, $n(\%)$ & $3(5 \cdot 6)$ \\
\hline Major vascular surgery, $n(\%)$ & $12(22 \cdot 6)$ \\
\hline \multicolumn{2}{|l|}{ Transient circulatory assistance } \\
\hline ECLS or Impella, $n(\%)$ & $5(9 \cdot 4)$ \\
\hline W ECMO, $n(\%)$ & $3(5 \cdot 6)$ \\
\hline Medical (cardiogenic shock), $n(\%)$ & $5(9 \cdot 4)$ \\
\hline
\end{tabular}

[I0], 25-75 interquartile; LVEF, left ventricular ejection fraction; SAPS II, Simplified Acute Physiology Score II; CABG, coronary artery bypass graft; LVAD, left ventricle assistance device; ECLS, veno-arterial extracorporeal life support; W ECMO, veno-venous extracorporeal membrane oxygenator.

\section{RBC Transfusions}

From 104 RBC transfusions, three were excluded due to change in patient's condition during transfusion: one for respiratory parameters, one for sedation score, one for norepinephrine dose increase and one was not included because $\mathrm{SvO}_{2}$, instead of $\mathrm{ScvO}_{2}$, was measured from a pulmonary artery catheter. Finally, 100 RBC transfusions were included in the study; the pre-transfusion characteristics are reported in Table 2.

Sixty-two RBC transfusions had available data on the cardiac function assessment by echocardiography (Doppler transaortic time velocity integral) before transfusion (Table 2). Twenty-eight RBC transfusions were performed in patients on circulatory support.

Fifty transfusions (50\%) were performed during mechanical ventilation, either in volume-controlled ventilation (76\%) or in pressure support ventilation (24\%).

Patients with assisted ventilation were sedated with a RASS score at $-4[-4-3]$ and BPS at 3 [3]. Fifty RBC transfusions were given to patients who were spontaneously breathing either with non-invasive ventilation $(n=5)$ or during nasal oxygen administration $(n=45)$, including high flow oxygen $(n=14)$. Before transfusion, $\mathrm{Hb} \quad$ was $\quad 7.2 \mathrm{~g} / \mathrm{dl} \quad[6.8-7.8] \quad$ vs. $7.2 \mathrm{~g} / \mathrm{dl} \quad[6 \cdot 8-7 \cdot 8)$ $(P=0.85)$, and Scv02 was $66 \cdot 7 \%[60-72]$ vs. $67 \cdot 1 \%[61-$ 79] $(P=0.94)$ for spontaneously breathing and extubated patients vs. intubated patients with assisted ventilation, respectively. Scv02 after transfusion was similar in both groups $72 \cdot 7 \%$ [66-75] vs. 71.5\% [66-77] $(P=0.94)$ for spontaneously breathing and extubated patients vs. intubated patients with assisted ventilation, respectively.

\section{Haemoglobin and $\mathrm{ScvO}_{2}$ changes after transfusion}

Anaemia was severe and was corrected appropriately by the transfusion protocol, with a median transfusion of 2 $[1,2] \mathrm{RBC}$ units (Table 3). $\mathrm{ScvO}_{2}$ increased significantly (Table 3) with a median delay between the two $\mathrm{ScvO}_{2}$ measurements of 137 minutes [90-290].

There was no significant correlation between the $\mathrm{Hb}$ level and $\mathrm{ScvO}_{2}$ before transfusion according to the Spearman analysis $[r=0.001$; (IC95: $-0.2-0 \cdot 2) P=0.99]$ (Fig. 1).

The best values of $\mathrm{ScvO}_{2}$ to predict an increase of $5 \%$, $10 \%, 15 \%$ and 20\% after transfusion were 65\%, 61.9\%, 60\% and 59\%, respectively (Table 3).

The area under the curve of the ROC curves increased with the level of $\mathrm{ScvO}_{2}$ change, mainly due to the increase in the sensitivity, reaching $100 \%$ at $20 \% \mathrm{ScvO}_{2}$ post-transfusion increase (Table 4). The $\mathrm{ScvO}_{2}$ of $65 \%$, which was associated with a $5 \% \mathrm{ScvO}_{2}$ increase after transfusion, had the best specificity and positive predictive value (Table 4) (Fig. 2). 


\begin{tabular}{|c|c|c|c|c|}
\hline & All $(n=100)$ & $\begin{array}{l}\operatorname{ScvO}_{2} \leq 65 \% \\
(n=42)\end{array}$ & $\begin{array}{l}\operatorname{ScvO}_{2}>65 \% \\
(n=58)\end{array}$ & $P^{\mathrm{a}}$ \\
\hline Delay form ICU admission, days, median [I0] & $4[1-11]$ & $3[1-11]$ & $4[1-11]$ & $0 \cdot 66$ \\
\hline AoTVI*, cm, median $[\mathrm{IO}]$ & $17[14-20]$ & $17[13-21]$ & $18[15-20]$ & $0 \cdot 97$ \\
\hline Norepinephrine, $n(\%)$ & $64(64)$ & $31(73 \cdot 8)$ & $33(56 \cdot 9)$ & $0 \cdot 12$ \\
\hline Inotrope, $n(\%)$ & $6(6)$ & $1(2 \cdot 3)$ & $5(8 \cdot 6)$ & $0 \cdot 34$ \\
\hline Lactate, mmol/l, median [I0] & $1 \cdot 6[1 \cdot 1-2 \cdot 2]$ & $1 \cdot 6[1 \cdot 1-2 \cdot 3]$ & $1 \cdot 7[1 \cdot 1-2]$ & 0.52 \\
\hline SOFA score, median [IO] & $7[4-14]$ & $6[4-14]$ & $7[4-14]$ & $0 \cdot 47$ \\
\hline Mechanical ventilation, $n(\%)$ & $50(50)$ & $17(40 \cdot 5)$ & $33(56.9)$ & $0 \cdot 11$ \\
\hline $\mathrm{SaO}_{2}, \%$, median $[\mathrm{IO}]$ & $100[98-100]$ & $100[98-100]$ & $100[98-100]$ & 0.47 \\
\hline
\end{tabular}

[10], 25-75 interquartile; AoTVI, Doppler transaortic velocity integral (* available in 62 cases); SOFA, Sequential Organ Dysfunction Score.

ap value between $\mathrm{ScvO}_{2} \leq 65 \%$ vs. $\mathrm{ScvO}_{2}>65 \%$.

Table 3 Effects of RBC transfusion

\begin{tabular}{|c|c|c|c|c|}
\hline & All $(n=100)$ & $\begin{array}{l}\mathrm{ScvO}_{2} \leq 65 \% \\
(n=42)\end{array}$ & $\begin{array}{l}\mathrm{ScvO}_{2}>65 \% \\
(n=58)\end{array}$ & $P^{\mathrm{a}}$ \\
\hline \multicolumn{5}{|l|}{ Before transfusion } \\
\hline $\mathrm{Hb}, \mathrm{g} / \mathrm{dl}$ & $7 \cdot 2[6 \cdot 8-7 \cdot 7]$ & $7 \cdot 2[6 \cdot 7-7 \cdot 6]$ & $7 \cdot 2[6 \cdot 8-7 \cdot 7]$ & $0 \cdot 61$ \\
\hline Heart rate, bpm & $89 \cdot 5$ [76-101] & 93 [75-106] & 86 [76-99] & $0 \cdot 27$ \\
\hline MAP, $\mathrm{mm} \mathrm{Hg}$ & $74[70-84]$ & $75[70-84]$ & $74\left[\begin{array}{ll}69 & 84\end{array}\right]$ & $0 \cdot 75$ \\
\hline $\mathrm{ScvO}_{2}, \%$ & $66 \cdot 9$ [60-73] & $58 \cdot 4[53-62]$ & $72[68-78 \cdot 9]$ & 0.001 \\
\hline $\mathrm{EO}_{2}, \%$ & $32.4[25 \cdot 9-39 \cdot 6]$ & $40 \cdot 2[36 \cdot 9-46 \cdot 1]$ & $26 \cdot 2[20 \cdot 7-31 \cdot 2]$ & 0.001 \\
\hline \multicolumn{5}{|l|}{ Transfusion } \\
\hline PRBC units & $2[1,2]$ & $2[1 \cdot 7-2]$ & $2[1,2]$ & 0.67 \\
\hline \multicolumn{5}{|l|}{ After transfusion } \\
\hline $\mathrm{Hb}, \mathrm{g} / \mathrm{dl}$ & $9.1[8.5-9.8]^{*}$ & $9 \cdot 1[8.5-9 \cdot 6]^{*}$ & $9[8 \cdot 6-9 \cdot 6]^{*}$ & 0.93 \\
\hline Heart rate, bpm & 90 [77-99] & $88[78-100]$ & 90 [76-99] & $0 \cdot 76$ \\
\hline $\mathrm{MAP}, \mathrm{mm} \mathrm{Hg}$ & 80 [74-90] & 80 [75-86] & 80 [72-90] & $0 \cdot 89$ \\
\hline $\mathrm{ScvO}_{2}, \%$ & $72[66-77]^{*}$ & $69[64-73]^{*}$ & 74 [69-79] & $0 \cdot 81$ \\
\hline $\mathrm{E}_{2}, \%$ & $28 \cdot 1[22 \cdot 6-33 \cdot 1]^{*}$ & $30 \cdot 3[26 \cdot 6-36 \cdot 1]^{*}$ & $24 \cdot 4[20 \cdot 9-31 \cdot 0]$ & 0.001 \\
\hline
\end{tabular}

$\mathrm{Hb}$, hemoglobin level; MAP, mean arterial pressure; $\mathrm{EO}_{2}, \mathrm{O}_{2}$ extraction as $\left(\mathrm{SaO}_{2}-\mathrm{ScvO}_{2}\right) / \mathrm{SaO}_{2}$ in \%; $\mathrm{PRBC}$, packed red blood cell. Data are expressed as Median [25-75 Interquartile].

${ }^{\text {a }} P$ value between $\mathrm{ScvO}_{2} \leq 65 \%$ vs. $\mathrm{ScvO}_{2}>65 \%$.

${ }^{*} P<0.001$ vs. before transfusion.

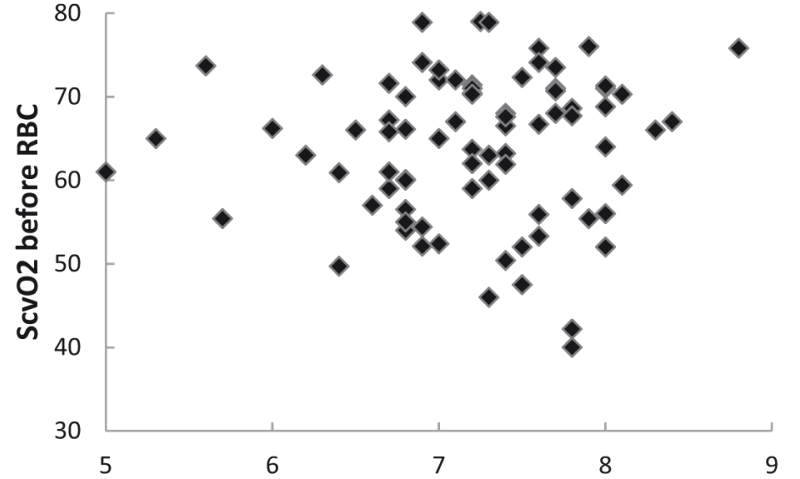

$\mathrm{Hb}$ before RBC

Fig. 1 Correlation between haemoglobin level $(\mathrm{Hb})$ and $\mathrm{ScvO}_{2}$ before transfusion. Haemoglobin level and $\mathrm{ScvO}_{2}$ are not correlated according to Spearman analysis $[r=0.001$; (I095: $-0 \cdot 2-0 \cdot 2), P=0.99]$.
Using this criterion to compare patients with or without $\mathrm{ScvO}_{2} \leq 65 \%$, we observed that the pre-transfusion characteristics were similar between both groups (Table 2). $\mathrm{Scv02}$ increased significantly only in patients with $\mathrm{ScvO}_{2}$ $\leq 65 \%$, while $\mathrm{Hb}$ increase was similar in both groups (Table 3).

There were no significant differences between both groups in hemodynamic measurements (Table 3). The lower $\mathrm{ScvO}_{2}$ in patients with $\mathrm{ScvO}_{2} \leq 65 \%$ was associated with a higher $\mathrm{EO}_{2}$ when compared to others (Table 3).

\section{Discussion}

This study shows that in patient, with severe anaemia $\mathrm{CHb}$ at $7.2 \mathrm{~g} / \mathrm{dl}$ ) in a cardiovascular and thoracic ICU, $\mathrm{ScvO}_{2}$ lower than $65 \%$ has a good positive predictive value 
20\%) improves the sensitivity of the $\mathrm{ScvO}_{2}$ cut-off value, but at the expense of specificity, down to $59 \%$. The lower the $\mathrm{ScvO}_{2}$ before transfusion, the higher the increase in $\mathrm{ScvO}_{2}$ after transfusion, which follows the physiology of $\mathrm{VO}_{2} / \mathrm{DO}_{2}$ dependence and may not be clinically relevant [20]. Therefore, choosing the $\mathrm{ScvO}_{2}$ with the best positive predictive value and specificity (65\%) seems the most appropriate strategy $[27,28]$. With a $65 \% \mathrm{ScvO}_{2}$ cut-off value, we were able to identify a fraction of anaemic situation $(42 \%)$, out of which more than $80 \%$ had a significant $\mathrm{ScvO}_{2}$ increase after blood transfusion. Our results suggest that RBC transfusion could have been possibly avoided in almost $60 \%$ anaemic patients with high $\mathrm{ScvO}_{2}$. For these patients, alternative treatments of anaemia, like intravenous iron supplementation or erythropoietin, could have been preferred to RBC transfusion. Indeed, assuming that high $\mathrm{ScvO}_{2}$ reflected normal $\mathrm{O}_{2}$ extraction, there was no need to correct anaemia urgently [29]. However, reducing $\mathrm{Hb}$ transfusion threshold with $\mathrm{ScvO}_{2}$ adjustment to calibrate restrictive transfusion strategy requires further studies; the impact of a $\mathrm{ScvO}_{2}$-directed restrictive strategy is already under investigation (NCT 02761564).

This study has several limits. First, it is a single-centre, observational study.

Second, although we attempted to avoid possible changes in clinical conditions, we cannot completely exclude that $\mathrm{ScvO} 2$ determinants besides $\mathrm{Hb}(\mathrm{CaO} 2, \mathrm{CO}$, EaO2) have changed during the observational period. However, no significant difference on hemodynamics between the two groups was noticeable before or after transfusion (Table 3).
Finally, the impact of the volume load related to the transfusion on the increase in cardiac performance is unknown as we did not measure $\mathrm{CO}$ in each patient. However, the absence of significant difference in hemodynamic status before and after transfusion, and similar volume of RBC transfusion between lower vs. higher $\mathrm{ScvO}_{2}$ make this hypothesis unlikely. Furthermore, if $\mathrm{ScvO}_{2}$ value during anaemia is useful to guide transfusion for correction of anaemia per se, it would help even further to correct 'anaemia with hypovolemia' eventually.

\section{In conclusion}

In this observational study in anaemic cardiovascular and thoracic ICU patients, in the absence of acute haemorrhage, $\mathrm{RBC}$ transfusion does not improve $\mathrm{ScvO}_{2}$ in patients with initial $\mathrm{ScvO}_{2}>65 \%$. Conversely, the change was significant when $\mathrm{ScvO}_{2}$ was below $65 \%$ before transfusion. Scv02 $\leq 65 \%$ could be a good threshold for tailoring $\mathrm{RBC}$ transfusion to metabolic need in anaemic patient. Further studies are required to assess if this strategy may affect long-term prognosis and transfusion strategy.

\section{Acknowledgement}

We would like to thank very much Miss Jessica WyneSamarani for her valuable help in revising the English writing.

\section{References}

1 Vincent JL, Baron J-F, Reinhart K, et al.: Anemia and blood transfusion in critically ill patients. JAMA 2002; 288:1499-1507

2 Corwin HL, Gettinger A, Pearl RG, et al.: The CRIT Study: anemia and blood transfusion in the critically illcurrent clinical practice in the United States. Crit Care Med 2004; 32:39-52

3 Thomas J, Jensen L, Nahirniak S, et al.: Anemia and blood transfusion practices in the critically ill: a prospective cohort review. Heart Lung 2010; 39:217-225

4 Society of Thoracic Surgeons Blood Conservation Guideline Task Force, Ferraris VAFerraris SPSaha SP, et al. Perioperative blood transfusion and blood conservation in cardiac surgery: the Society of Thoracic Surgeons and
The Society of Cardiovascular Anesthesiologists clinical practice guideline. Ann Thorac Surg 2007; 83: S27-S86

5 Walsh TS, Saleh E, Lee RJ, et al.: The prevalence and characteristics of anaemia at discharge home after intensive care. Intensive Care Med 2006; 32:1206-1213

6 Walsh TS, Garrioch M, Maciver C, et al.: Red cell requirements for intensive care units adhering to evidence-based transfusion guidelines. Transfusion 2004; 44:1405-1411

7 Hajjar LA, Vincent JL, Galas FR, et al.: Transfusion requirements after cardiac surgery: the TRACS randomized controlled trial. JAMA 2010; 304:15591567. https://doi.org/10.1001/jama.2010. 1446
8 Karkouti K: Transfusion and risk of acute kidney injury in cardiac surgery. $\mathrm{Br} J$ Anaesth 2012; 109(Suppl 1):i29-i38

9 Koch CG, Li L, Duncan AI, et al.: Transfusion in coronary artery bypass grafting is associated with reduced long-term survival. Ann Thorac Surg 2006; 81:1650-1657

10 Dietrich W, Faraoni D, von Heymann C, et al.: ESA guidelines on the management of severe perioperative bleeding: comments on behalf of the Subcommittee on Transfusion and Haemostasis of the European Association of Cardiothoracic Anaesthesiologists. Eur J Anaesthesiol 2014; 31:239-241

11 Hébert PC, Fergusson DA, Stather D, et al.: Revisiting transfusion practices in critically ill patients. Crit Care Med 2005; 33:7-12 
12 Sakr Y, Lobo S, Knuepfer S, et al.: Anemia and blood transfusion in a surgical intensive care unit. Crit Care 2010; 14:R92

13 DeFoe GR, Ross CS, Olmstead EM, et al.: Lowest hematocrit on bypass and adverse outcomes associated with coronary artery bypass grafting. Northern New England Cardiovascular Disease Study Group. Ann Thorac Surg 2001; 71:769-776

14 Vincent J-L, Sakr Y, Sprung C, Sepsis Occurrence in Acutely Ill Patients (SOAP) Investigators, et al.: Are blood transfusions associated with greater mortality rates? Results of the Sepsis Occurrence in Acutely Ill Patients study. Anesthesiology 2008; 108:31-39

15 Murphy GJ, Pike K, Rogers CA, et al.: Liberal or restrictive transfusion after cardiac surgery. $N$ Engl J Med 2015; 372:997-1008

16 Reinhart K, Rudolph T, Bredle DL, et al.: Comparison of central-venous to mixed-venous oxygen saturation during changes in oxygen supply/demand. Chest 1989; 95:1216-1221

17 Reinhart K, Kuhn H-J, Hartog C, et al.: Continuous central venous and pulmonary artery oxygen saturation monitoring in the critically ill. Intensive Care Med 2004; 30:1572-1578
18 Kozek-Langenecker SA, Afshari A, Albaladejo P, et al.: Management of severe perioperative bleeding: guidelines from the European Society of Anaesthesiology. Eur $J$ Anaesthesiol 2013; 30:270-382

19 Dyke C, Aronson S, Dietrich W, et al.: Universal definition of perioperative bleeding in adult cardiac surgery. $J$ Thorac Cardiovasc Surg 2014; 147:1458-1463. e1

20 Schumacker PT, Cain SM: The concept of a critical oxygen delivery. Intensive Care Med 1987; 13:223-229

21 Pölönen P, Ruokonen E, Hippeläinen $\mathrm{M}$, et al.: A prospective, randomized study of goal-oriented hemodynamic therapy in cardiac surgical patients. Anesth Analg 2000; 90:1052-1059

22 Marik PE, Sibbald WJ: Effect of stored-blood transfusion on oxygen delivery in patients with sepsis. JAMA 1993; 269:3024-3029

23 Donati A, Loggi S, Preiser J-C, et al.: Goal-directed intraoperative therapy reduces morbidity and length of hospital stay in high-risk surgical patients. Chest 2007; 132:1817-1824

24 Pearse R, Dawson D, Fawcett J, et al.: Changes in central venous saturation after major surgery, and association with outcome. Crit Care 2005; 9: R694-R699

25 Bracht H, Hänggi M, Jeker B, et al.: Incidence of low central venous oxygen saturation during unplanned admissions in a multidisciplinary intensive care unit: an observational study. Crit Care 2007; 11:R2

26 Vallet B, Robin E, Lebuffe G: Venous oxygen saturation as a physiologic transfusion trigger. Crit Care 2010; 14:213

27 Fryback DG, Thornbury JR: The efficacy of diagnostic imaging. Med Decis Making 1991; 11:88-94

28 Moons KG, Stijnen T, Michel BC, et al.: Application of treatment thresholds to diagnostic-test evaluation: an alternative to the comparison of areas under receiver operating characteristic curves. Med Decis Making 1997; 17:447-454

29 Society of Thoracic Surgeons Blood Conservation Guideline Task Force, Ferraris VA, Brown JR, Despotis GJ, et al. 2011 update to the Society of Thoracic Surgeons and the Society of Cardiovascular Anesthesiologists blood conservation clinical practice guidelines. Ann Thorac Surg 2011;91:944982 